\title{
Duck fleas as evidence for eiderdown production on archaeological sites
}

\author{
Véronique Forbes \\ University of Aberdeen, School of Geosciences, Department of Archaeology, St Mary's Building, \\ Elphinstone Road, Aberdeen AB24 3UF, UK \\ Telephone: + 44 (0) 1224 273701; Fax: + 44 (0) 1224272331 \\ Email: v.forbes@abdn.ac.uk
}

\begin{abstract}
:
Eiderdown has long been an important resource for northern cultures in the past but is overlooked in archaeology. Down, presumed to be from Eider ducks, has only been identified from a handful of high-status burials in Scandinavia. In order to test whether an archaeoentomological indicator for eiderdown production could be established, a survey of insects from two eiderdown productions sites in Iceland was conducted. The results identified over 500 duck fleas Ceratophyllus garei Rothschild and several beetle species from raw eiderdown and processing residue, as well as from pitfall traps placed in the floor of buildings where the down was stored and processed. It is argued that despite the fact that bird fleas parasitic on Eider ducks are not host-specific, their life history and microhabitat requirements, as well as the method employed to collect eiderdown, makes duck fleas a reliable indicator for eiderdown harvesting in archaeology.

\section{Highlights:}

- The importance of eiderdown as a trade and prestige item in northern Europe is discussed.

- Results of a survey of modern insects from eiderdown production sites are presented.

- Duck fleas are recognized as reliable indicators of eiderdown production.
\end{abstract}

Keywords: archaeoentomology; archaeoparasitology; eiderdown; Eider ducks; bird fleas; trade

\section{Introduction}

Eiderdown has long been an important resource for many northern cultures. The down was a prestige item, used in the past (not unlike today) to fill luxury quilts, pillows and outdoor clothing. Eiderdown is harvested in coastal areas of Iceland, Canada, Greenland, Denmark, northern Norway and arctic Russia (Shrubb, 2013; Skarphédinsson, 1996). In Iceland, it was such an important part of the economy that from the $13^{\text {th }}$ century AD, Eider ducks were managed and protected by law (Doughty, 1979). Even though the Icelandic annual production of eiderdown remained within 2500 to $4300 \mathrm{~kg}$ during the last half-century, its market value increased from c. 760 to 2200000 US \$ during the same period (Bédard et al., 2008; Doughty, 1979). Despite the antiquity of this important resource, the role of eiderdown exploitation in ancient northern economic and subsistence systems is largely overlooked in archaeology, undoubtedly because of the small size and delicate nature of down feathers, which make them difficult to recover and identify. The origin of eiderdown collection, use and trade has so far only been inferred from mentions in registers, ethnographic accounts and natural history books (e.g. see Doughty, 1979; Shrubb, 2013), in addition to a few exceptionally well preserved finds from Viking Age burials in Scandinavia. All the records of down and feathers mentioned in Berglund's (2009) review of the archaeological evidence regarding the eiderdown trade come from such contexts. Although these records clearly demonstrate that down and feathers were used in bedclothes at least from the $7^{\text {th }}$ century $A D$, they reveal little regarding eiderdown harvesting and trade. Indeed, it remains unclear where, how and from which bird species these feathers and down were collected and processed before they ended up in funerary contexts.

Eiderdown is the down that the female Eider duck pulls from her body to construct her nest and expose her brood patch (an area of featherless skin on the belly that helps transferring heat to the 
eggs). It is highly prized because of its insulating properties, lightness, cohesion and resilience, as well as the fact that it is completely devoid of coarse feathers (Bédard et al., 2008). The absence of such coarse feathers is due to the fact that unlike geese and other ducks' down, eiderdown is collected from nests rather than plucked from live or dead birds (Bédard et al., 2008; Schrubb, 2013). Although other waterfowl use down to construct their nests (Johnsgard, 1968), only the down of Eider ducks, most commonly the common Eider (Somateria mollissima), is known to have been harvested in such a way (Schrubb, 2013). Before it can be used or sold, the raw eiderdown needs to be dried and cleaned. Traditional methods employed for this purpose in Scandinavia consisted of casting the down onto a wooden frame to which several strings were attached, then moving it briskly in such a way that the down remained on the frame, while impurities contained in the raw down fell to the ground (Berglund, 2009; Doughty, 1979; Annandale, 1905). As bird nests are microhabitats for various insect species, some of which are specialized feeders on bird blood, skin, feathers or faeces (Collias and Collias, 1984; Hicks, 1959), this debris would presumably have included some insects. Notably, Bédard et al. (2008) mention the need to rid eiderdown of the bird fleas it contains.

Presuming raw eiderdown does contain insects, would these insects be found on production sites? Studies of macrofossils from British and Scandinavian sites have shown that domestic and industrial processes can leave diagnostic traces in the archaeological record in the form of insect and plant remains. For example, Buckland and Sadler (1989) demonstrated that the most likely source of the concentration of sheep keds Melophagus ovinus (L.) and lice Bovicola (=Damalinia) ovis (L.) they recovered from $17^{\text {th }}$-century Stóraborg in Iceland was likely to be wool processing residue. Another example comes from the work of Hall and Kenward (2011), who interpreted the recovery of certain plant and insects remains (i.e. decayed bark, bark sclereids, animal ectoparasites and beetles ecologically associated with either bark or carrion) as indicative of different stages of leather production.

This paper presents a study of insects from Icelandic farm buildings used as eiderdown stores and workshops. It aims to test the potential of archaeoentomology, the analysis of insect remains preserved in archaeological contexts, to help in investigating the origin and development of the eiderdown industry and, more specifically, to determine whether specific insect taxa can be considered indicative of eiderdown production activities.

\section{Methods}

The study focuses on the sites of Æđðey and Vatnsfjörður, both located in the north-western region of Iceland called the 'Westfjords' (Fig. 1), historically one of the most productive areas in the country for eiderdown (Doughty, 1979). EEđey is a small private island located at the centre of Ísafjarđadjúp where eiderdown colonies still breed at the present day. Here, a small wooden building serving for the storage of raw eiderdown (Fig. 2A) was investigated. Fieldwork took place on the $24^{\text {th }}$ and $25^{\text {th }}$ of September 2010, at which time the building still contained several large bags of raw eiderdown (Fig. 2B). At Vatnsfjörður, the survey took place in an old sheep house converted into a workshop for eiderdown processing (Fig. 2C). The building had wooden slatted floors, under which there was old sheep manure. It still contained feeding troughs, three of which served for drying and cleaning eiderdown and were covered with the chicken wire that had been used in this process. At the time of investigation ( $2^{\text {nd }}$ and $3^{\text {rd }}$ August 2010), the eiderdown itself had been removed from the buildings, but debris that originated from it was left on the feeding troughs and also covered the ground.

The survey of insects present in the two buildings was undertaken by means of pitfall trapping and hand collection. Pitfall traps were used to capture living insects crawling on the ground surface. They 
were made of plastic cups (100mm diameter, $140 \mathrm{~mm}$ height) placed in holes dug in the ground and sunk in a way that their lid was level with the surface. Each cup was half-filled with water, to which a few drops of washing liquid and vinegar were added (to break the water surface and keep the insects soft). The traps were left to function for a period of 24 hours, after which the insects captured were collected and stored in alcohol. Hand collection involved placing raw eiderdown and cleaning debris on a bright orange bivouac bag (Fig. 2D) and searching through them. Insects were collected using forceps and an aspirator before being placed in alcohol. Table 1 and Fig. 3 provide

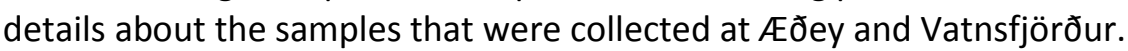

Upon completion of the fieldwork, beetles (Coleoptera) were mounted on pins and identified through comparisons with reference specimens from the entomological collection at Náttúrufræđistofnun Íslands (Institute of Natural History of Iceland) in Reykjavík and from the Laurentian Forestry Centre's René Martineau Insectarium in Quebec City. Images, keys and descriptions from entomological publications (Bousquet, 1990; Strand and Vik, 1966; Warner and Negley, 1976; Woodroffe and Coombs, 1961) were also used. Flea (Siphonaptera) specimens were mounted on temporary slides, some of them after having been cleared following the method described by Brinck-Lindroth and Smith (2007). This allowed them to be compared with reference specimens as well as illustrations and descriptions provided in Brinck-Lindroth and Smit (2007) and Smith (1957). The taxonomy employed in this study is based on Ólafsson's checklist of Icelandic insects (1991) and the nomenclature used for the Coleoptera follows Böhme (2005).

\section{Results}

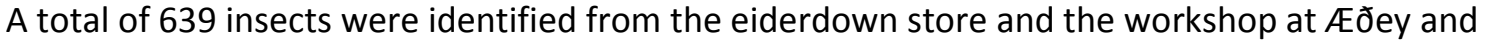
Vatnsfjörður, which includes 581 fleas and 58 beetles (Table 2). The large majority of the fleas (486 specimens) were obtained from hand collected samples. In contrast, most beetles (40) came from pitfall traps. While pitfall traps exclusively collected insects that were living at the time of capture, hand collected samples produced both live and dead, sometimes disarticulated, insects.

The sample collected from stored eiderdown at Æđđey (A2) allowed the recovery of 112 specimens of the duck flea Ceratophyllus garei Rothschild (Fig. 4), a species which infest birds nesting on damp ground (Brinck-Lindroth and Smit, 2007) and which has been recorded from Eider ducks nests in Iceland (Henriksen, 1939). The further 14 Ceratophyllus specimens recovered may belong to the same species, but since it was not possible to differentiate them between $C$. garei and $C$. borealis Rothschild, they were left at genus level. Specimens intermediate between the two species have been noted in Iceland (Henriksen, 1939; Rothschild, 1955). Like C. garei, C. borealis prefers birds nesting on marshy ground and/or near the sea. The species has been recorded on white wagtails (Motacilla alba) and red-necked phalaropes (Phalaropus lobatus) in Iceland (Henriksen 1939). Apart from ten specimens, all the fleas recovered from sample A2 were alive, though inactive, at the moment of their capture.

The sample collected from eiderdown processing residue at Vatnsfjörður (V9) also produced 19 live duck flea specimens that were active at the time of capture. Beetles were represented by the disarticulated sclerites from two species, Calathus melanocephalus (L.) and Otiorhynchus arcticus (O. Fabricius). Both are very common in Iceland. The former is a ground beetle (fam. Carabidae) mostly encountered in rather dry grasslands and the latter is a weevil (fam. Curculionidae) known to occur in almost all kinds of outdoor terrestrial biotopes in the country (Larsson and Gígja, 1959).

Of the two samples collected from the top of the wooden floor of the eiderdown store at $\mathbb{E}$ đey, the first one (A3) included six dead specimens of Ceratophyllus sp. and 2 live specimens of $C$. garei. The second sample (A4) produced as many as 349 dead insects, including 16 beetles and 333 fleas. Once 
again, most of the fleas (320) were identified to C. garei; others were left at genus level

(Ceratophyllus). Disarticulated or partially disarticulated beetle sclerites were also recovered and the taxa they belong to span three families: the ground beetles (Carabidae), the water scavenger beetles (Hydrophilidae) and the silken fungus beetles (Cryptophagidae). Atomaria analis Erichson is synanthropic in Iceland, where it is able to exploit a variety of decaying plant remains, although it has mostly been recorded from mouldy hay (Larsson and Gígja, 1959). The genus Cercyon Leach is mostly terrestrial and detritivorous. The preferred ecological niches of the four Cercyon species found in Iceland include manure and plant waste in various synanthropic and natural settings (Larsson and Gígja, 1959). Calathus melanocephalus is again present, found alongside two other ground beetles: Nebria rufescens (Ström) and Patrobus septentrionis (Dejean). N. rufescens is a circumpolar and eurytopic species that can be found in a diverse array of outdoor situations in Iceland, while $P$. septentrionis prefers moist ground and is most commonly encountered in meadows (Gudleifsson, 2005; Larsson and Gígja, 1959).

The assemblages obtained from pitfall traps at Vatnsfjörður and ÆEđey (samples A1 and V1 to V8) differ from each other. At $\mathbb{E} \circlearrowright$ Jy, the species diversity is very low, with an assemblage comprising 72 duck fleas Ceratophyllus garei and two ground beetles Calathus melanocephalus. Although the assemblage from Vatnsfjörður is similarly dominated by Ceratophyllus garei, it also includes a fairly high number of spider beetles (fam. Ptinidae) Tipnus unicolor (Pill. \& Mitt.). This species is considered a strong synanthrope in Iceland, where it has only ever been encountered indoors (Larsson and Gígja, 1959). It is known, however, to occur in the wild in old wood and bird's nests in Britain (Fowler, 1890; Howe, 1955). Beetles associated with decaying vegetation were also collected by pitfall traps, including the predacious rove beetle (fam. Staphylinidae) Xylodromus concinnus (Marsham) and the silken fungus beetle Cryptophagus distinguendus Sturm. Specimens of $C$. melanocephalus, of the outdoor weevil Tropiphorus obtusus (Bonsdorff), and of the rove beetles Oxypoda cf. soror Thomson and Oxypoda sp. were captured as well. Apart from T. obtusus and $O$. soror, all these beetle taxa have been recorded at least once from bird's nests (see Hicks, 1959).

\section{Discussion}

The two buildings that have been examined as part of this study were used for slightly different stages of eiderdown production. One of them (ÆđJey) served for the storage of eiderdown; the other (Vatnsfjörður) was used for its processing. This provided an opportunity to examine insect faunas associated with the different types of materials involved, including the down itself, processing residues and debris that accumulated on the floors of the buildings. There is one thing almost all the samples collected have in common: the presence of the duck flea $C$. garei. It was especially abundant in samples collected from raw down and from floor debris in the eiderdown store, which suggest that the fleas were introduced inside along with the eiderdown harvest. Since 19 live duck fleas were also recovered from processing residue at Vatnsfjörður, it appears that they remained and survived indoors even after the bulk of the down had been taken away from the buildings.

The disarticulated state of many of the beetles recovered from eiderdown processing residue suggests these specimens were dead long before they were collected. They may have originated in the nests from which the down was collected, perhaps brought there or consumed by the birds, or they may have exploited the microhabitats created within the nests. The spider beetle $T$. unicolor, which was present in six of the eight pitfall traps placed in the sheep house at Vatnsfjörður, is able to feed on a variety of animal and vegetal substances. It would have been able to survive on the organic materials present in the old sheep house. The species is considered a strong synanthrope in Iceland, having never been encountered in natural habitats on the island. However, as the species is known to be able to exploit nest habitats elsewhere in northern Europe (Fowler, 1890; Hicks, 1959; Howe, 1955), the possibility for it to have entered the buildings along with materials collected from 
nests cannot be completely ruled out. Larsson \& Gígja's (1959, p. 167) remark on the larvae's association with bird and rodent excrements, and on the fact that this biotope may not have been investigated for beetle faunas in Iceland, is significant. Although it is not impossible that some of the other beetles recovered also originated in bird's nests (see Hicks, 1959), they could also have entered the buildings either by flight or crawling (in the case of outdoor beetles), or they could have been living in the various microhabitats provided by the organic materials present. Since all the beetle species identified from Æđðey and Vatnsjförður are known to be able to survive and complete their development cycles away from birds and their nests, only the duck flea $C$. garei may be considered indicative of eiderdown production activities. Before this can be validated, a number of issues need to be considered.

Unlike host-specific ectoparasites such as lice (Phthiraptera), fleas are mobile, do not spend their whole lifecycle on the body of their hosts and often have more than one host species (Marshall, 1981; Rothschild and Clay, 1957). For most bird fleas, suitable habitat conditions are determined by the moisture level, temperature and emplacement of the nest, rather than by the bird species associated with it. The duck flea $C$. garei prefers damp nests on or near the ground and is able to feed on the blood of many birds nesting in such settings (Brinck-Lindroth and Smit, 2007; Marshall, 1981). In Iceland, these include Eider ducks, but also gulls, larks and plovers (Henriksen, 1939). Other Ceratophyllus species, such as the hen flea $C$. gallinae, can successfully breed in association with mammals (Rotschild and Clay, 1957; Tripet and Richner, 1997), but $C$. garei's narrower habitat requirements suggest it is unlikely to be able to reproduce away from damp bird's nests.

The lack of host-specificity in bird fleas means that it would be possible for specimens of Ceratophyllus species, including $C$. garei, to end up in the archaeological record as a result of the exploitation of birds other than Eider ducks. In Iceland, many seabirds were exploited for their meat, eggs and feathers (Beck, 2013; Petersen, 2005), all of which may have caused the transport of bird fleas. However, given that adult and larval stages of bird fleas spend the largest part of their lives in nests rather than on birds, only the transport of materials collected from nests into buildings are likely to introduce a large number of fleas indoors. There is no evidence that the feathers of other bird species, besides Eider ducks, were collected directly from nests. The feathers of other species, therefore, must have been procured as a by-product of hunting or poultry farming (from plucking dead or live birds) or simply by collecting naturally shed feathers (Albarella, 2005; Beck, 2013; Shrubb, 2013). Such practices may cause remains of feather lice (Mallophaga) to end up on archaeological sites, since these arthropods cling to the host's feathers (Rothschild and Clay, 1957), but they are unlikely to introduce large quantities of bird fleas.

The identification of disarticulated Siphonaptera remains from archaeological deposits poses certain difficulties. As pointed out by Yvinec et al. (2000), while it may be possible to identify some fleas to the level of species just from the characteristics of the cephalic capsule (head), this is unlikely to be feasible for most ceratophyllids, for which observation of the genitalia is required. Since not all Ceratophyllidae species are parasites of birds (Brinck-Lindroth and Smit, 2007), identification to species, or at least genus, is desirable. This can only be achieved if flea abdomens and reproductive parts are preserved. Archaeological subfossils of human flea Pulex irritans L. are relatively abundant (e.g. Buckland et al., 1998; Forbes and Milek, 2014; Kenward and Hall, 1995) and there are also a few records of dog, cat and rodent fleas (see Kenward, 2009), but bird fleas have rarely been identified from archaeological sites. A few remains of fleas identified as Ceratophyllus vagabundus (Boheman) were collected from a Saqqaq occupation dated to the $2^{\text {nd }}$ millennium BC in Greenland (Böcher and Fredskild, 1993). However, the only site where large numbers of bird fleas were recovered from archaeological layers is Vatnsfjörður, where late $19^{\text {th }}$ and early $20^{\text {th }}$ century deposits produced nearly 200 specimens (Forbes et al., 2010). Thanks to the excellent preservation conditions of organics in these sediments, many flea abdomens were found and it was possible to confidently identify 58 of 
these to C. garei, the duck flea (Forbes, 2013; Forbes et al., 2013). The recovery of duck fleas at Vatnsfjörður not only allowed the first identification of eiderdown production on an archaeological site, but also demonstrated that where suitable preservation conditions occur, bird flea abdomens and genitalia can be preserved and identified.

It important to note that apart from C. garei, there are other flea species that infest the nests of Eider ducks, including C. vagabundus (Boheman), C. borealis and Mioctenopsylla arctica Rothschild (Brinck-Lindroth and Smit, 2007; Coulson et al., 2009; Hicks, 1959; Pilskog et al., 2014). These could therefore also be suitable indicators for eiderdown production on archaeological sites, provided they are found in high numbers.

\section{Conclusion}

This study has demonstrated that by using archaeoentomological methods, it is possible to identify eiderdown harvesting in the archaeological record. At two extant eiderdown production sites in northern Iceland, the duck flea $C$. garei was found to be associated with recently harvested eiderdown. This suggests that when fleas parasitic on ground-nesting seabirds, including the duck flea C. garei, are found in high quantities alongside organic debris likely derived from nests - such as down feathers, egg shell fragments, dry grass and seaweed - they can be considered as ecofactual evidence for eiderdown. Archaeoentomology therefore provides the only known means to recognize eiderdown production sites in archaeology. It would be highly desirable to collect samples for insect fossil analysis on archaeological sites located in proximity to Eider ducks breeding grounds, as combined efforts to track eiderdown production sites and to identify eiderdown use in domestic and funerary contexts should eventually elucidate the origin and development of eiderdown use and trade.

\section{Acknowledgements}

This project was undertaken as part of my doctoral studies funded by the Commonwealth Scholarship Commission in the United Kingdom. I would like to thank my supervisors Karen Milek and Andrew Dugmore for their help and support. I also wish to thank Jónas Helgason, his son Alexius Jónasson and Baldur Vilhelmsson for kindly having allowed access to the eiderdown stores and workshops at $\mathbb{E} \circlearrowright$ ¿y and Vatnsfjörður and for having provided assistance when needed. I would like to thank Fornleifastofnun Íslands for supporting my fieldwork at Vatnsfjörđur, as well as Paul Ledger and Garðar Guðmundsson for their help during fieldwork. I am especially grateful to Richard Marriott for his invaluable help with flea identifications and for lending me reference material. Erling Ólafsson and Jan Klimaszewski also helped with the beetle identifications. Consultation of the BugsCEP database (Buckland and Buckland, 2006) aided the redaction of this paper.

\section{References}

Albarella, U., 2005. Alternate fortunes? The role of domestic ducks and geese from Roman to Medieval times in Britain. In: Grupe, G. , Peter, J. (Eds.), Feathers, Grit and Symbolism: Birds and Humans in the Ancient Old and New Worlds. Verlag Marie Leidorf, Rahden, pp. 249-258.

Annandale, N., 1905. The Faroes and Iceland: Studies in Island Life. Clarendon Press, Oxford.

Beck, S.G., 2013. Exploitation of wild birds in Iceland from the settlement period to the $19^{\text {th }}$ century and its reflection in archaeology. Arch. Is. 10, 28-52. 
Bédard, J., Nadeau, A., Giroux, J.-F., Savard, J.-P.L., 2008. Eiderdown: Characteristics and Harvesting Procedures. Société Duvetnor Ltée and Canadian Wildlife Service, Environment Canada, Québec.

Berglund, B., 2009. Fugela feđerum in archaeological perspective - eider down as a trade commodity in Prehistoric northern Europe. Acta Boreal. 26 (2), 119-135.

Böcher, J., Fredskild, B., 1993. Plant and arthropod remains from the Palaeo-Eskimo site on Qeqertasussuk, West Greenland. Meddelelser om Grønland, Geoscience 30.

Böhme, J., 2005. Die Käfer Mitteleuropas. K. Katalog (Faunistiche Übersicht) (2nd ed.). Spektrum Academic, Munich.

Bousquet, Y., 1990. Beetles Associated with Stored Products in Canada. An Identification Guide. Ministry of Supply and Services, Ottawa.

Brinck-Lindroth, G., Smit, F.G.A.M., 2007. The Fleas (Siphonaptera) of Fennoscandia and Denmark. Fauna Entomologica Scandinavica, vol. 41. Brill, Leiden.

Buckland, P.C., Buckland, P.I., Skidmore, P., 1998. Insect remains from GUS: an interim report. In: Arneborg, J., Gulløv, H.C. (Eds.), Man, Culture and Environment in Ancient Greenland. Dansk Polar Centre \& Danish National Museum, Copenhagen, pp.74-79.

Buckland, P.C., Perry, D.W., 1989. Ectoparasites of sheep from Stóraborg, Iceland and their interpretation. Hikuin 15, 37-46.

Buckland, P.I., Buckland, P.C., 2006. BugsCEP Coleopteran Ecology Package. IGBP PAGES/World Data Center for Paleoclimatology Data Contribution Series \# 2006-116. NOAA/NCDC Paleoclimatology Program, Boulder CO, USA. URL: http://www.ncdc.noaa.gov/paleo/insect.html \& http://www.bugscep.com. Accessed 16 January 2012.

Collias, N.E., Collias, E.C., 1984. Nest Building and Bird Behavior. Princeton University Press, Princeton.

Coulson, S.J., Moe, B., Monson, F., Gabrielsen, G.W., 2009. The invertebrate fauna of High Arctic seabird nests: the microarthropod community inhabiting nests on Spitsbergen, Svalbard. Polar Biology 32, 1041-1046.

Doughty, R.W., 1979. Eider husbandry in the North Atlantic: trends and prospects. Polar Rec. 122, 447-459.

Forbes, V., 2013. Evaluation of archaeoentomology for reconstructing rural life-ways and the process of modernisation in $19^{\text {th }}$ - and early $20^{\text {th }}$-century Iceland. Ph.D. Dissertation, University of Aberdeen, UK.

Forbes, V., Bain, A., Gisladóttir, G.A., Milek, K.B., 2010. Reconstructing aspects of the daily life in late $19^{\text {th }}$ and early $20^{\text {th- }}$ century Iceland: archaeoentomological analysis of the Vatnsfjörður farm, NW Iceland. Arch. Is. 8, 77-110.

Forbes, V., Dussault, F., Bain, A., 2013. Contributions of ectoparasite studies in archaeology with two examples from the North Atlantic region. International J. Paleopathol. 3, 158-164. 
Forbes, V., Milek, K.B., 2014. Insects, activity areas and turf buildings' interiors: an ethnoarchaeoentomological case study from $19^{\text {th }}$ to early $20^{\text {th }}$-century Pverá, Northeast-Iceland. Quaternary International 341, 195-215.

Fowler, W.W., 1890. The Coleoptera of the British Islands. Vol. IV: Lamellicornia-SerricorniaLongicornia-Phytophaga. L. Reeve \& co., London.

Gudleifsson, B.E., 2005. Beetles species (Coleoptera) in hayfields and pastures in northern Iceland. Agriculture, Ecosystems Environ. 109, 181-186.

Hall, A. , Kenward, H., 2011. Plant and invertebrate indicators of leather production. In: Thomson, R., Mould, Q. (Eds.), Leather Tanneries. The Archaeological Evidence. Archetype Publications, London, pp. 9-32.

Henriksen, K.L., 1939. Siphonaptera. Volume III, Part 47. In: Friðriksson, Á, Tuxen, S.L. (Eds.), The Zoology of Iceland. Ejnar Munksgaard, Copenhagen.

Hicks, E.A., 1959. Check-List and Bibliography on the Occurrence of Insects in Birds' Nests. lowa State College Press, Ames.

Howe, R.W., 1955. Studies on beetles of the family Ptinidae 12. The biology of Tipnus unicolor (Pill. \& Mitt.). Entomologist Monthly Mag. 91, 253-257.

Johnsgard, P.A., 1968. Waterfowl: Their Biology and Natural History. University of Nebraska Press, Lincoln.

Kenward, H., 2009. Northern Regional Review of Environmental Archaeology: Invertebrates in Archaeology in the North of England. Research Department Report Series (12/2009), English Heritage, Portsmouth.

Kenward, H.K., Hall, A.R., 1995. Biological Evidence from 16-22 Coppergate. Archaeology of York, 14/7. Council for British Archaeology for York Archaeological Trust, York.

Larsson, S.G., Gígja, G., 1959. Coleoptera 1. Synopsis. Volume III, Part 46a. In Friđriksson, Á., Tuxen, S.L. (Eds.), The Zoology of Iceland. Ejnar Munksgaard, Copenhagen.

Marshall, A.G., 1981. The Ecology of Ectoparasitic Insects. Academic Press, London.

Ólafsson, E., 1991. Íslenskt Skordýratal. Fjölrit Náttúrufraeđistofnunar, Reykjavík.

Petersen, A., 2005. 9. Traditional seabird fowling in Iceland. In: Traditions of Sea-bird Fowling in the North Atlantic Region. Islands Book Trust, Isle of Lewis, pp. 194-215.

Pilskog, H.E., Solhøy, T., Gwiazdowicz, D.J., Grytnes, J.-A., Coulson, S.J., 2014. Invertebrate communities inhabiting nests of migrating passerine wild fowl and sea birds breeding in the High Arctic, Svalbard. Polar Biology 37, 981-998.

Rothschild, M., 1955. The distribution of Ceratophyllus borealis Rothschild, 1906 and C. garei Rothschild, 1902, with records of specimens intermediate between the two. Transactions Royal Entomological Society Lond. 107 (1-14), 295-318. 
Rothschild, M., Clay, T., 1957. Fleas, Flukes and Cuckoos. A Study of Bird Parasites. The MacMillan Company, New York.

Shrubb, M., 2013. Feasting, Fowling and Feathers - A History of the Exploitation of Wild Birds. T. \& A.D. Poyser, London.

Skarphédinsson, K.H., 1996. The common Eider - some ecological and economical aspects. Bull. Scandinavian Society Parasitology 6 (2), 90-97.

Smit, F.G.A.M., 1957. Siphonaptera. Handbooks for the Identification of British Insects 1 (16). Royal Entomological Society, London.

Strand, A., Vik, A., 1964. Die Genitalorgane der Nordischen Arten der Gattung Oxypoda Mannh. (Col. Staphylinidae'. Norsk Entomologisk Tidsskrift 13, 169-175.

Tripet, F., Richner, H., 1997. The coevolutionary potential of a 'generalist' parasite, the hen flea Ceratophyllus gallinae. Parasitology 115, 419-427.

Warner, R.E., Negley, F.B., 1976. The genus Otiorhynchus in America north of Mexico (Coleoptera: Curculionidae). Proc. Entomological Society Wash. 78 (3), 240-262.

Woodroffe, G.E., Coombs, C.W., 1961. A Revision of the North American Cryptophagus Herbst (Coleoptera: Cryptophagidae). Entomological Society of America, Washington.

Yvinec, J.H., Ponel, P., Beaucournu, J.-Cl., 2000. Premier apports archéoentomologiques de l'étude des puces: aspects historiques et anthropologiques (Siphonaptera). Bull. Société Entomologique Fr. 105 (4), 419-425. 


\section{Tables and figures}

Table 1. List of entomological samples collected from the eiderdown store at $Æ$ Edey and the eiderdown workshop at Vatnsfjörður.

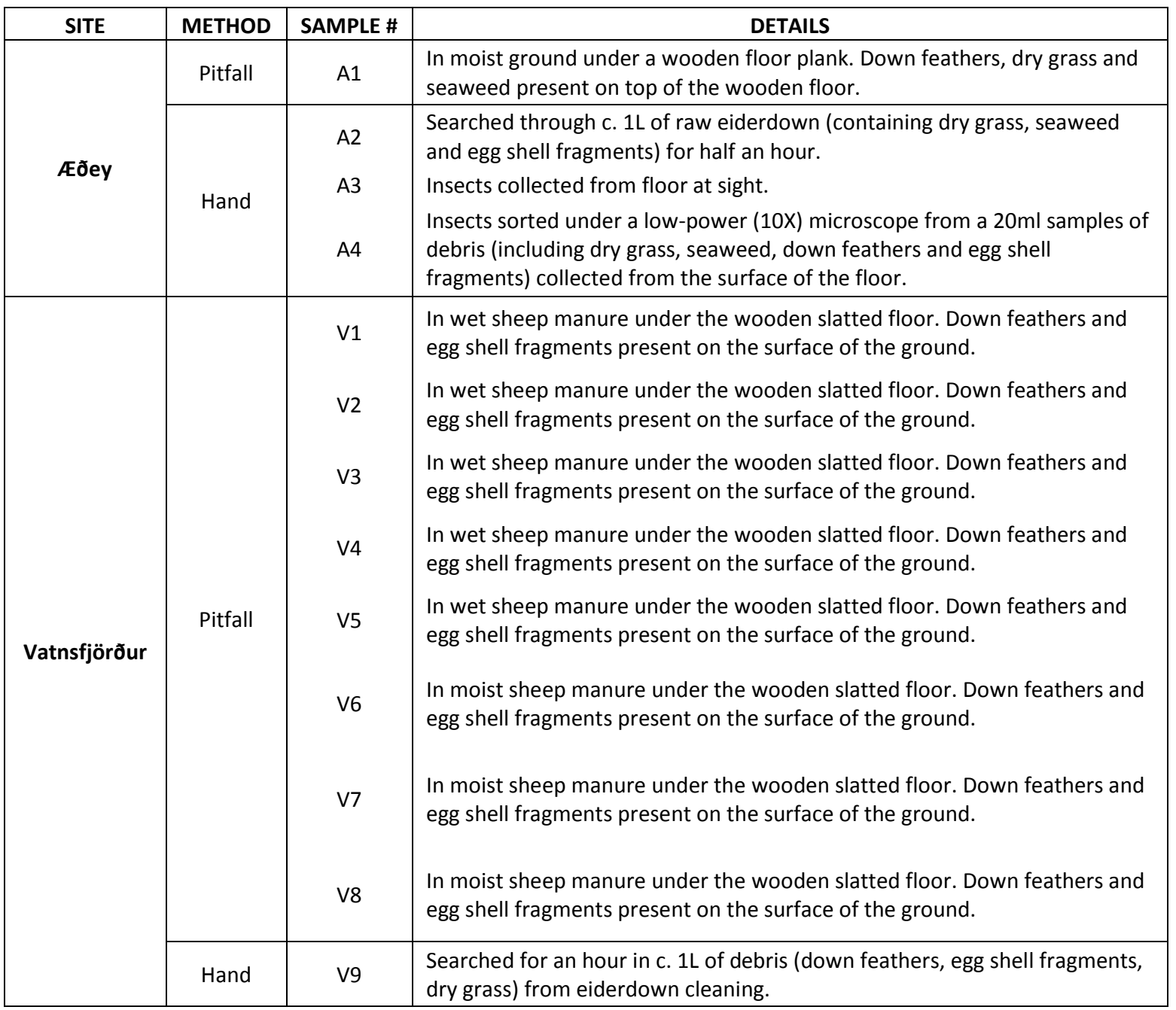


Table 2. List of identified insects from ÆEđey and Vatnsfjörður. Italicized numbers indicate counts of specimens that were dead at the time of collection.

\begin{tabular}{|c|c|c|c|c|c|c|c|c|c|c|c|c|c|}
\hline & A1 & A2 & A3 & A4 & V1 & V2 & V3 & V4 & V5 & V6 & V7 & V8 & V9 \\
\hline \multicolumn{14}{|l|}{ COLEOPTERA } \\
\hline \multicolumn{14}{|l|}{ CARABIDAE } \\
\hline Nebria rufescens (Ström) & & & & 3 & & & & & & & & & \\
\hline Patrobus septentrionis (Dejean) & & & & 2 & & & & & & & & & \\
\hline Calathus melanocephalus (Linnaeus) & 2 & & & 8 & & 1 & & 4 & & & & & 2 \\
\hline \multicolumn{14}{|l|}{ HYDROPHILIDAE } \\
\hline Cercyon sp. & & & & 1 & & & & & & & & & \\
\hline \multicolumn{14}{|l|}{ STAPHYLINIDAE } \\
\hline Xylodromus concinnus (Marsham) & & & & & & & 1 & 1 & & & 1 & & \\
\hline Oxypoda cf. soror Thomson & & & & & & & & & & 1 & & & \\
\hline Oxypoda sp. & & & & & & & & & & & 1 & & \\
\hline \multicolumn{14}{|l|}{ PTINIDAE } \\
\hline Tipnus unicolor (Piller \& Mitterpacher) & & & & & & & 3 & 13 & 2 & 1 & 4 & 2 & \\
\hline \multicolumn{14}{|l|}{ CRYPTOPHAGIDAE } \\
\hline Cryptophagus distinguendus Sturm & & & & & & & & & & & & 1 & \\
\hline Atomaria analis Erichson & & & & 2 & & & & & & & & & \\
\hline \multicolumn{14}{|l|}{ CURCULIONIDAE } \\
\hline Otiorhynchus arcticus (O. Fabricius) & & & & & & & & & & & & & 1 \\
\hline Tropiphorus obtusus (Bons dorff) & & & & & & & 1 & & & & & & \\
\hline \multicolumn{14}{|l|}{ SIPHONAPTERA } \\
\hline \multicolumn{14}{|l|}{ CERATOPHYLLIDAE } \\
\hline Ceratophyllus garei Rotschild & 72 & $110(+2)$ & 2 & 320 & 5 & & 2 & 6 & 4 & 2 & 1 & 3 & 19 \\
\hline Ceratophyllus sp. & & $6(+8)$ & 6 & 13 & & & & & & & & & \\
\hline TOTAL & 74 & 126 & 8 & 349 & 5 & 1 & 7 & 24 & 6 & 4 & 7 & 6 & 22 \\
\hline
\end{tabular}

Figure 1. Maps showing the location of the study sites: A) Map of the northernmost part of the North Atlantic region, B) Map of Iceland, C) Location of $Æ$ Eðey and Vatnsfjörður.
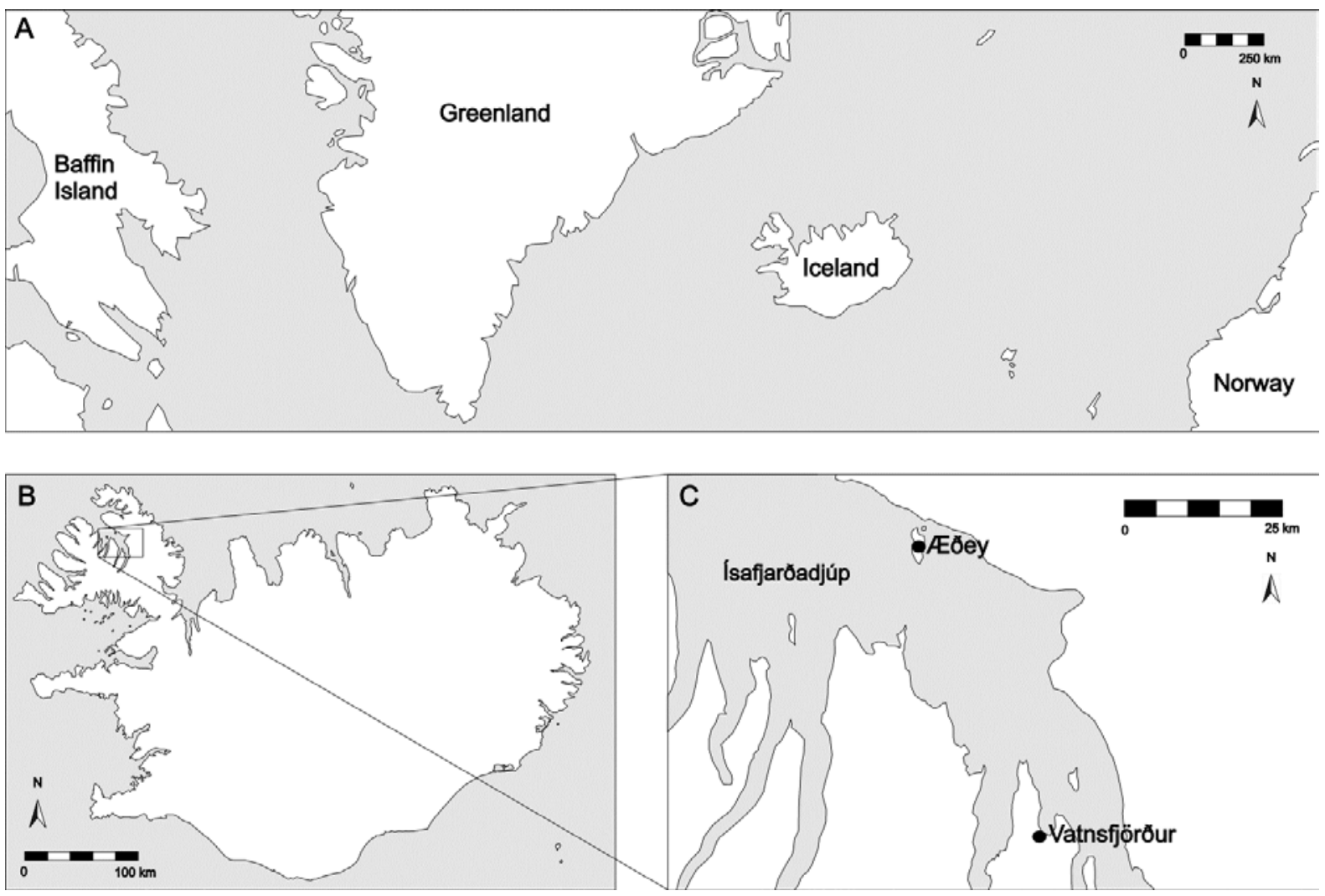
Figure 2. Photographs of the examined buildings and of some of the materials sampled: A) the eiderdown store at $\mathbb{E} \circlearrowright$ dey, B) Close-up on raw eiderdown from $\mathbb{E} \circlearrowright$ Jey, C) the eiderdown workshop at Vatnsfjörður, D) Close-up on debris from raw eiderdown.
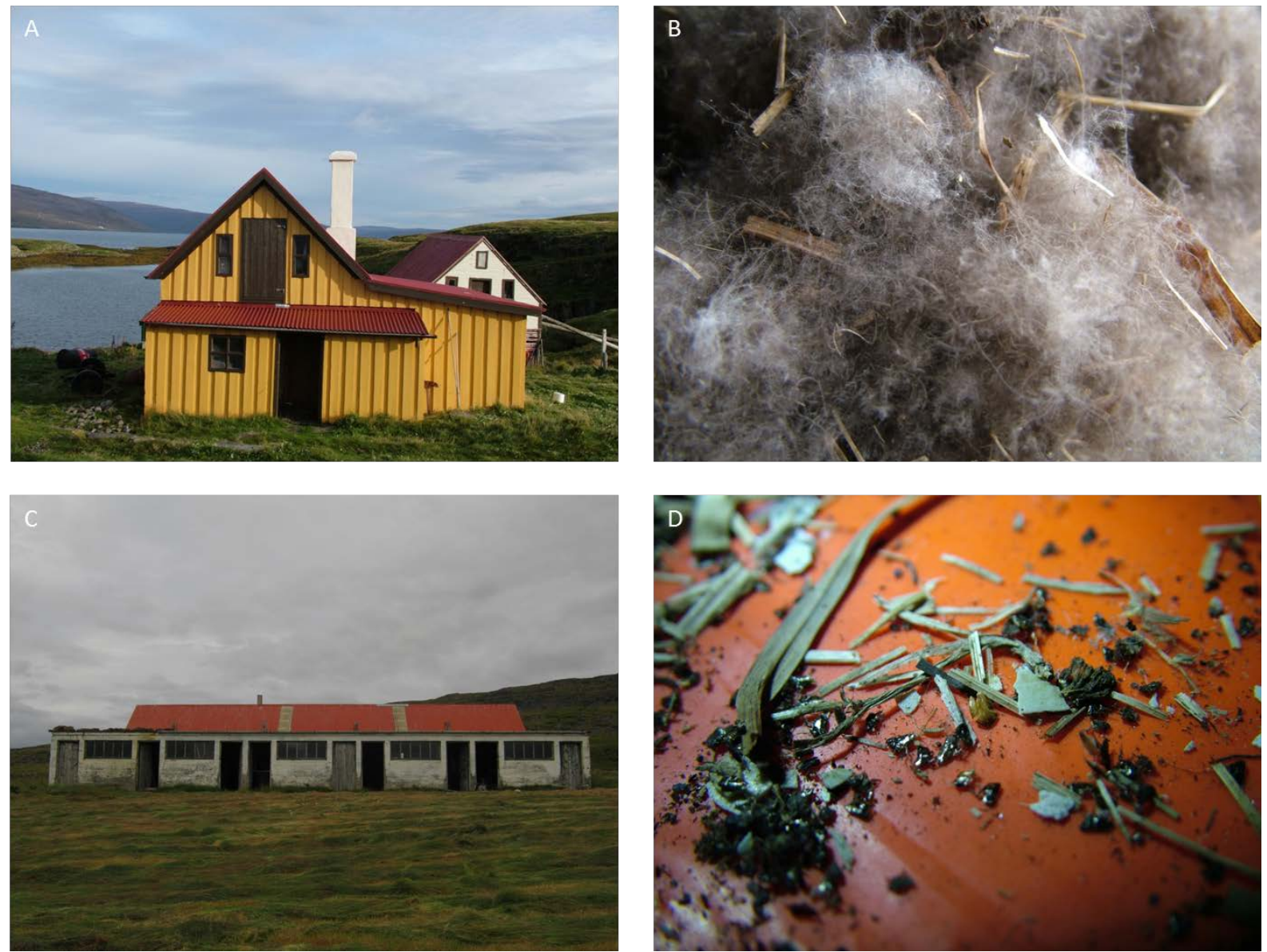

Figure 3. Plan of the examined buildings showing the locations where samples were collected: A) the eiderdown store at $\mathbb{E} \circlearrowright$ Jey, B) the eiderdown workshop at Vatnsfjörður.
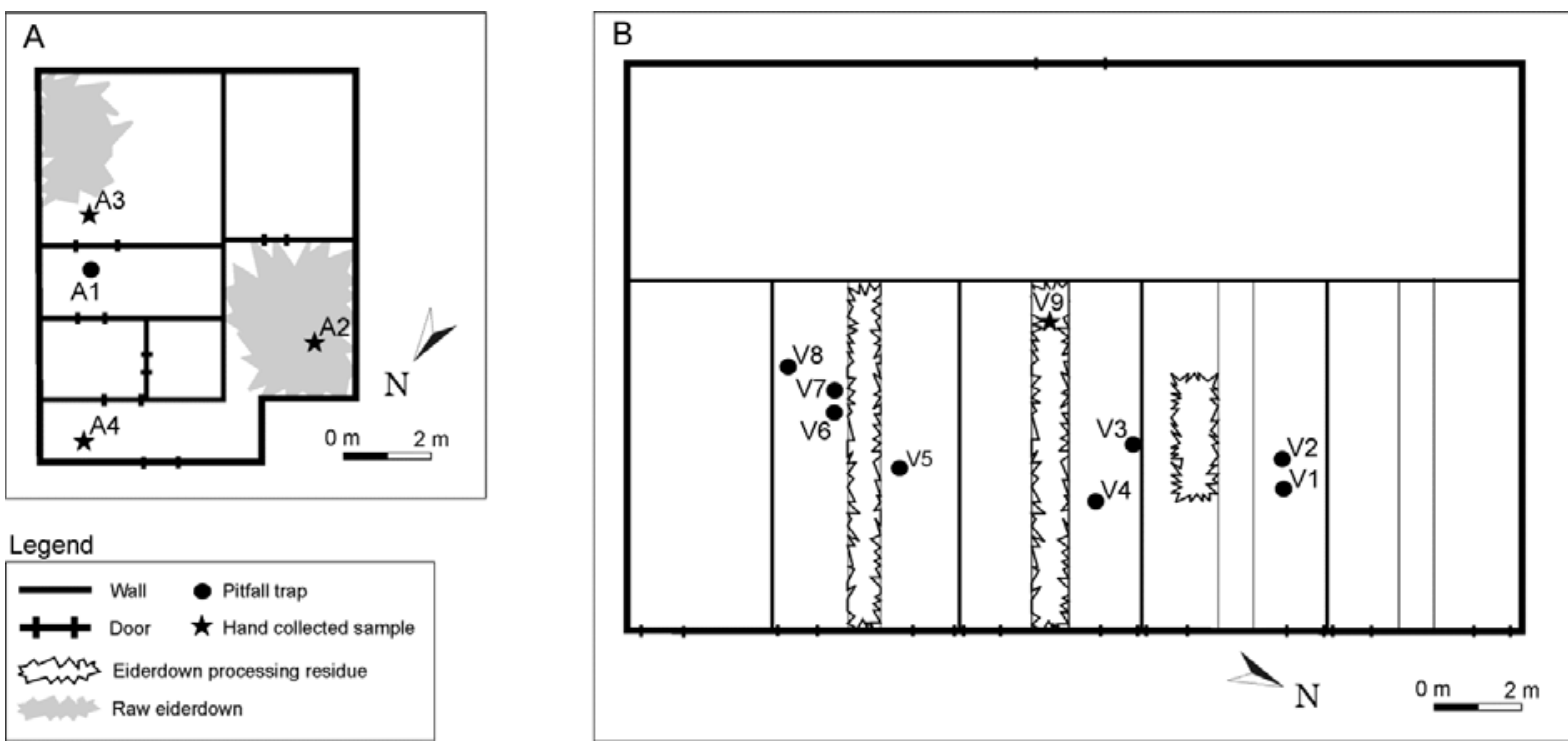
Figure 4. Male and female duck fleas ( $C$. garei) from $\mathbb{A} \circlearrowright$ đey. Note that on this picture, the spermatheca (female reproductive organ) is slightly inclined laterally.

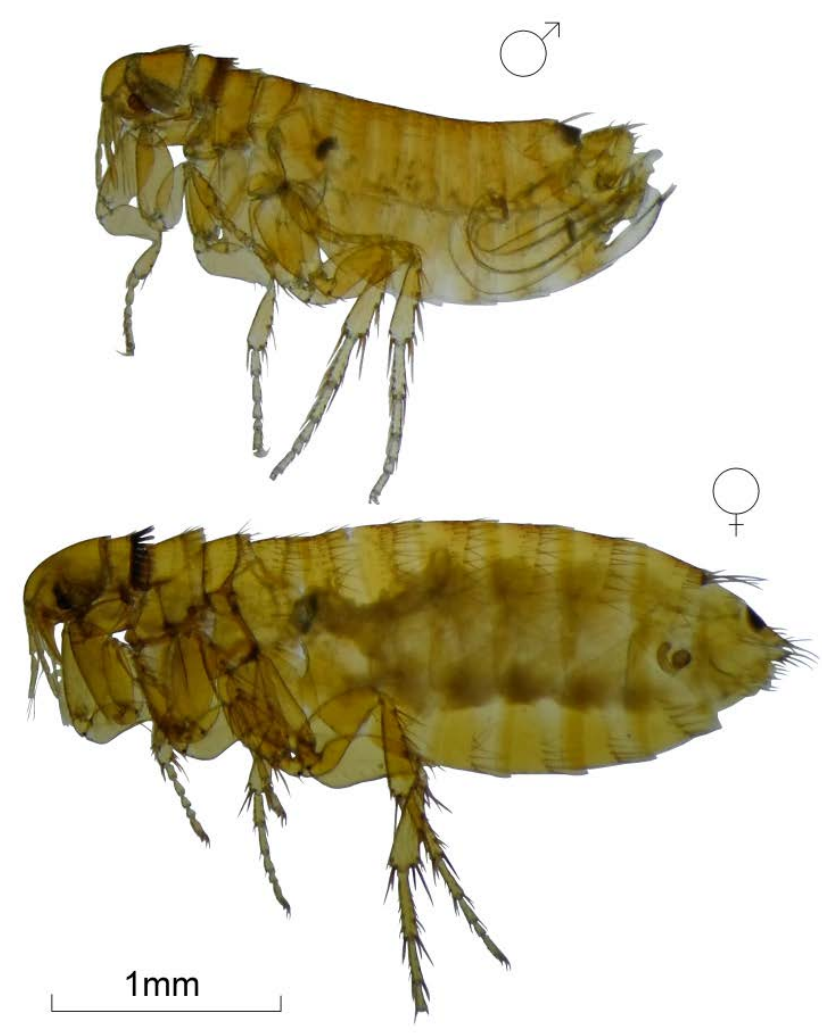

